\title{
70 Years After the DeClaration of INDEPENDENCE - Is There a Coherent Immigration Policy in Israel?
}

\author{
Rami Goldstein \\ https:// orcid.org/0000-0001-9822-0762 \\ (Bar Ilan University, Israel) \\ e-mail: Golds.office@gmail.com
}

Keywords: Israel, immigrants, immigration policy, Law of Return, refugees, asylum seekers, infiltrators, Israel independence, international law

\begin{abstract}
This article examines the immigration policy in Israel 70 years after the nation's Declaration of Independence. Israel was established in an attempt to create a shelter for Jews in the Diaspora. Therefore, the policy of Israel towards immigrants has been sometimes criticized as being racist, discriminatory, or undemocratic. But is there a coherent immigration policy in Israel? In fact, aside from the Law of Return of 1950, which refers exclusively to Jewish immigrants, Israel still lacks a proper legal framework that can regulate foreign immigration. In many cases, immigration policy in Israel seems to be unclear and incoherent. With today's reality of the global migration crisis, this legal vacuum represents a dangerous gap that prevents the State of Israel from effectively coping with the problem with respect to international law and humane standards.

This paper will critically review the major features of current immigration policies, such as the policy of "direct absorption," the expulsion of African immigrants, and the new procedures of the asylum seekers' process in Israel.
\end{abstract}

\section{Introduction}

With the establishment of the State of Israel in 1948, two thousand years of exile were officially over. The nature of the new State of Israel was seen as a state to which Jews returned from exile, not as immigrants to a foreign country, but as people returning to their homeland. Therefore, immigration to Israel has unique characteristics.

Immigration policy is a natural part of an open economy and society. Immigration control policy is a central element in deciding on the nature and rate of allowed migration into a country. One of the most complicated problems facing Israel, as well as Europe today, is how to deal with asylum seekers and people in search of work arriving daily, some escaping nations where poverty and persecution are, for them, a routine fact of life. Migration policy in general is a tool designed to promote the interests of the state and public life. However, Immigration Control Policy, just like any other policy, should be managed in the best interests of a particular state. ${ }^{1}$ Immigration control can be

${ }^{1}$ Zapata-Barrero 2010: 326-329; Zolberg 1998. 
distinguished from the broader concept of immigration policy by its emphasis on state policies that define the permissible level of foreign citizens that can enter a state. ${ }^{2}$ The common relevant and usual policy questions in most developed states are: who will be allowed to enter the state, and how many people should be allowed to immigrate for the benefit of the state? ${ }^{3}$ But the situation in Israel is quite different. This article examines the immigration policy in Israel 70 years after the Declaration of Independence. The research question is: do we actually have a coherent immigration policy in Israel? In order to answer this question, we will review in summary the main trends of immigration to Israel since the Declaration of Independence in 1948.

We will also examine the current phenomenon of foreign immigration to Israel, including African economic migrants, so-called "infiltrators," and the new wave of nonJewish immigrants into Israel. As part of that examination, this paper will critically review the major features of current immigration policies, such as the policy of "direct absorption," the expulsion of African immigrants, and the new procedures of the asylum seekers' process in Israel.

\section{The main trends of Jewish immigration to Israel since the Declaration of Independence}

Jewish immigration to Israel is different from most other immigrant societies because the Jewish people are not viewed as economic migrants but as a "Returning Diaspora." Since Israel is considered the homeland of the Jewish people, every Jew has the right to return there. Jewish immigrants are thus referred to not as regular immigrants, but as Olim. ${ }^{4}$

The State of Israel was established in 1948 with a population of approximately 800,000 people. In 2018 , Israel had a population of more than 8.4 million: $76 \%$ Jewish, $20 \%$ Arabic, and $4 \%$ others. The Jewish people in Israel come from many backgrounds. About $73 \%$ are Israeli-born, while 18\% are Jews from North America and Europe, and almost $9 \%$ are from Africa and Asia. It must be added that Jewish people from the former Soviet Union and their Israeli-born descendants account for a high percentage of the Jewish population in Israel. ${ }^{5}$

Despite its unique characteristics, Israel has long been viewed as the prototype of an immigrant society, a society inhabited mostly by Jewish immigrants and by the sons and daughters of these immigrants. Immigration has not only accounted for the dramatic increase in the size of the Jewish population, but it has also changed the ethnic composition of Israeli society, making its population much more heterogeneous. ${ }^{6}$

However, in comparison to the challenge of absorbing thousands of Jews, most of them refugees, after the Second World War and the proclamation of the State of Israel

${ }^{2}$ Money 1999: 2-8.

${ }^{3}$ Hollifield, Martin, Orrenius 2014: 3-8.

${ }^{4}$ Olim (Hebr.) - new immigrants. A term with a positive connotation, meaning ascending or going up to settle in their homeland. See: Semyonov, Lewin-Epstein 2003: 327-337.

${ }^{5} \mathrm{http} / / /$ worldpopulationreview.com/countries/israel-population/.

${ }^{6}$ Semyonov, Gorodezeisky 2012: 147-163. 
three years later, the problem of assimilation was not so acute or complex in the period before the establishment of Israel. For obvious situational and historical reasons, immigrants from Europe constituted the absolute majority of the old population, before Israel was established, and the cultural or ethnic rift dividing the community into two parts was not yet conspicuous. This situation has changed drastically with the establishment of Israel, forcing the young state to rise to the challenge of the large-scale immigration of oriental Jewish refugees escaping from Arabic states, and a smaller but important group of Holocaust survivors. The arrival of the latter constituted a dividing line in the development of Israel national identity. However, immigration has had a very important role in the development of Israel's population. ${ }^{7}$

As has been previously said, since Israel is considered the homeland of the Jewish people, Jews are referred to not as immigrants but as Olim. Likewise, immigration is referred to as Aliyah. ${ }^{8}$ Aliyah is an important element in the collective identity of Israeli society. Following this logic, Israel applies a system of jus sanguineous for inclusion of Jewish immigrants in society, while excluding non-Jewish immigrants. ${ }^{9}$ In this context it would be wrong to call Israel's immigration policy a discriminatory one, racist or anti-democratic. This system is clearly evident in the Law of Return (1950) ${ }^{10}$ and the Nationality Law (1952). ${ }^{11}$ According to these laws, every Jew and family member of Jewish immigrants has the right to settle in Israel and to be awarded Israeli citizenship upon arrival. The state not only enables Jewish immigrants and family members to make Israel their home, but it also provides generous financial and institutional support to ease their transition from their country of origin and to facilitate their integration into society during their initial years in the new country. ${ }^{12}$

Based on the above laws, immigration to Israel is mainly possible per the Aliyah process, which is available to persons with Jewish roots eligible under the Law of Return. Clause 4A (a) of the Law of Return states as follows:

The rights of a Jew under this law, and the rights of an Ole under the Citizenship Law of 1952, and the rights of an Ole under any other law, are given to the child or grandchild of a Jew, the spouse of a Jew the spouse of a child and grandchild of a Jew; Except a person who was born Jewish and out of his free will converted his religion.

According to the Law of Return, the right to live and settle in Israel is given to eligible persons per the law and definition above. Eligible persons per the Law of Return considering settlement in Israel may choose from among several options, one of which provides a B/1 Work Visa for several years. Another is a process which provides temporary residence while considering Aliyah. This process also makes them eligible for social rights such as health care. In addition, the eligible person may choose to undergo Aliyah, whether with the help of the Jewish Agency abroad or individually at the Ministry of

\footnotetext{
7 Semyonov, Lewin-Epstein 2003: 327-328, note 4.

${ }^{8}$ Aliyah (Hebr.) - immigration of Jewish people to the State of Israel.

9 For further discussion on the Israeli nationality Law and the system of jus sanguineous in Israel see: Rubinstein 1976: 159.

${ }^{10}$ Law of Return, 5710-1950, S.H. 5710, 159; 4 L.S.I. 114.

11 The Nationality Law, 5712-1952. S.H. 5712, 146; 6 L.S.I. 50.

12 Semyonov, Gorodezeisky 2012.
} 
Interior offices in Israel. ${ }^{13}$ The Aliyah process includes presenting personal documents and proof of Jewish roots. In general, most Jews and those of Jewish origin are eligible to undergo Aliyah and to receive Israeli citizenship. This process is called "direct absorption." Any new immigrant is entitled to financial assistance ("absorption basket"). Types of assistance given to individual immigrants include: the absorption basket, a grant complementary to the absorption basket, a grant for customs charges and minimum wages compensation, and other grants in accordance with various programs..$^{14}$

During the establishment of the State of Israel, there were, as mentioned, only approximately 800,000 residents. In 1949 , the population crossed the one million mark. One of the high points of immigration to Israel was between 1948 and 1951, when 600,000 immigrants from Arabic countries and Europe immigrated to Israel. Nine years later, in 1958, the population crossed the two million mark, indicating a positive population growth rate.

In early 1994, Israel had a population of approximately 5.3 million people. Of this, $81.5 \%$ were Jewish, $14.1 \%$ were Muslim, $2.7 \%$ were Christian, and $1.7 \%$ was comprised of Druze and others. The main factor leading to positive population growth was the large number of Jewish immigrants that arrived from all corners of the world. In 1948-1951, approximately 687,000 arrived on the shores of the State of Israel. The majority of these were survivors from the Nazi extermination camps located in Europe, as well as members of communities whose migration originated from Arab countries in Asia and North Africa. ${ }^{15}$

As a result of this Jewish immigration, Israel's population doubled in less than four years. In 1955-57, 1961-64 and 1969-74, smaller groups of migrants also settled in the country. The growth increment in these years was $30-45 \%$, with $35-50 \%$ of this figure being a result of the migration balance. The influx arising from migration was sometimes low, and in 1974 it settled to an all-time low until 1990-93, when thousands of Jews migrated from the collapsing Soviet Union.

The immigration, as well as stability in natural population increase, resulted in a population growth from $17 \%$ in the 1980 s (of which migration accounted for $6 \%$ ) to $40 \%$ (of which migration contributed over two-thirds). Emigration from Israel, though playing a small part, was also significant in the migration balance, as it significantly reduced the population. Many of the emigrants were people who were eligible according to the process of "direct absorption." "Most of these emigrants were Russian Jews who received the absorption basket, and many of them left Israel after a short time. ${ }^{17}$ Israel also absorbed many Ethiopian Jews during the 1980s and 1990s.

The rate of natural population growth decreased from 21.6 per thousand in the late 1950s to 15-17 per thousand recorded in 2010, despite fluctuations in the past decade. Some of the factors leading to the decrease were life expectancy and fertility rate, as well as age structures of different population groups.

\footnotetext{
13 Berger 1969.

14 Koch-Davidovich 2011: 4.

15 For further information on the immigration of Jews from Arab countries see: Laskier 2006.

16 Semyonov, Lewin-Epstein 2003: 336, note 4.

17 Philippov 2008. Available at: https://en.idi.org.il/articles/6754.
} 
The fertility rate, or the number of children women were bearing, fluctuated under different population groups in the 1950s and 1960s. Well-off families were able to keep the number of children down, while poor families saw the number of children born shoot up. In the 1960s, the fertility rate was more than 9 children per woman among Muslims and about 3.4 children per woman among Jews. It then dropped in the 1970s and 1980s. Total fertility declined among Asian/African Jews, Christians, Muslims and the Druze as well as European/American Jews. The rates were 2.61 among Jews, 4.68 for Muslims, 2.03 among Christians and 3.76 for Druze and others. As a typical population growth rate for a developed country, the State of Israel has a rapid growth rate. Since the establishment of Israel, the population has increased approximately tenfold, primarily as a result of the high rates of immigration of Jews into the country. ${ }^{18}$ Using the statistics available, projections of Israel's population can be made, showing approximate population trends:

Table 1. Facts about the population of Israel ${ }^{19}$

\begin{tabular}{|c|}
\hline Population in Israel (as of March 2018) \\
\hline $8,433,045$ \\
\hline Total area of Israel \\
\hline $22,070 \mathrm{~km}^{2}\left(8,521 \mathrm{mi}^{2}\right)$ \\
\hline Population density \\
\hline 382.1 per km² $\left(989.6\right.$ people $\left./ \mathrm{mi}^{2}\right)$ \\
\hline Sex ratio \\
\hline $0.97(4,162,997$ men to $4,270,310$ women $)$ \\
\hline Median age \\
\hline 30.2 years \\
\hline Life expectancy \\
\hline 81.0 years $(78.8-$ men, $83.2-$ women $)$ \\
\hline
\end{tabular}

As shown in Table 1, at the beginning of March 2018, the total population in Israel was $8,433,045$. The median age was 30.2 and life expectancy was 81 years. If we compare these data to January 2018, the population of Israel, as of 1 January 2018, was estimated to be $8,407,396$ people. As of 1 January 2017, the population of Israel was $8,269,949$. Therefore, the population growth between 2017 and 2018 was 1.66\% (137,447 people). In 2017 the natural increase was positive, as the number of births exceeded the number of deaths by 133,312 . Due to external migration, the population in Israel increased by 4,135. The sex ratio of the total population was 0.970 (970 males per 1,000 females), which is lower than the global sex ratio.

\footnotetext{
${ }^{18} \mathrm{http}$ ///worldpopulationreview.com/countries/israel-population.

$19 \mathrm{http}: / /$ countrymeters.info/en/Israel\#facts. Population figures are only estimates based on United Nations data.
} 
Table 2. Israel population history ${ }^{20}$

\begin{tabular}{|c|c|c|}
\hline Year & Population & Nowth Rate \\
\hline 1951 & $1,306,034$ & $7.41 \%$ \\
\hline 1952 & $1,402,795$ & $6.85 \%$ \\
\hline 1953 & $1,498,866$ & $6.15 \%$ \\
\hline 1954 & $1,591,013$ & $5.43 \%$ \\
\hline 1955 & $1,677,371$ & $3.47 \%$ \\
\hline 1965 & $2,482,914$ & $3.13 \%$ \\
\hline 1975 & $3,288,161$ & $2.07 \%$ \\
\hline 1980 & $3,707,966$ & $1.66 \%$ \\
\hline 1985 & $4,049,505$ & $3.64 \%$ \\
\hline 1994 & $5,074,777$ & $3.41 \%$ \\
\hline 1995 & $5,247,762$ & $2.14 \%$ \\
\hline 2000 & $5,952,487$ & $1.97 \%$ \\
\hline 2005 & $6,536,861$ & $2.27 \%$ \\
\hline 2010 & $7,341,666$ & $1.56 \%$ \\
\hline 2015 & $8,001,760$ & $1.66 \%$ \\
\hline 2016 & $8,134,749$ & $1.66 \%$ \\
\hline 2017 & $8,269,949$ & $1.66 \%$ \\
\hline 2018 & $8,407,396$ & \\
\hline & & \\
\hline
\end{tabular}

As shown in Table 2, in 1951 there were 1,306,034 inhabitants in Israel. However, in 1965 the population in Israel almost doubled and the number of inhabitants reached 2,482,914 people. In 1995 there were 5,247,762 people living in Israel.

The main reason for this growth was the high immigration of Jews from the former Soviet Union into the country. ${ }^{21}$ Ten years after, in 2010 there were 7,341,666 people living in Israel and at the beginning of 2018 the number was 8,407,396. In April 2020 the population of Israel reached 8,731,200. ${ }^{22}$

\section{The current phenomenon of foreign immigration to Israel}

Migration may be divided into that which is the effect of forced migration, and that which is voluntary. Human migration is a worldwide phenomenon that is on the rise. Millions of men and women leave their countries to enter other countries to find employment and personal and economic security, but there are millions who have been forced

20 http://countrymeters.info/en/Israel\#facts.

21 Della Pergola 2000: 42-43.

22 https://countrymeters.info/en/Israel\#population_2020. 
to migrate. ${ }^{23}$ There are many factors that motivate human migration from one country to another. They include widespread poverty, civil wars, natural disasters, gaps in wages and living standards between countries, increased industrialization, and reduced costs of transport and communications. ${ }^{24}$ However, practice and new research have shown that the distinction between forced and voluntary migration is often blurred, and there may be a range of mixed motivations behind migration. ${ }^{25}$ Part of this movement of labour migrants concerns non-professional workers or semi-professionals, who are invited to work in developed countries where unemployed locals refuse to work in specific fields of employment. The migrant workers are mainly employed in jobs considered the most dangerous and difficult. These jobs are referred to as "the three D's": dirty, dangerous and difficult. ${ }^{26}$

Illegal immigrants were present in Israel in small numbers as early as the 1970s, but only in the 1980s did it enter the public discourse in Israel. Illegal immigrants were mainly civilians from South America, Africa, and the Philippines. Until the late 1980s, foreign immigration to Israel was in small numbers, illegal and spontaneous.

After the end of the first intifada in 1992 - and the Israeli Government's decision to recruit foreign workers to fill positions of Palestinian workers - Israel allowed the entry of about 100,000 voluntary foreign workers, who received permits as prescribed by law. The State of Israel began to deal with this phenomenon as a problem in 1997, when attempts were made to prevent the entry of more immigrants, beyond those who has been permitted entry. A large part of those who entered the country lawfully lost their right to stay in Israel for various reasons, but they did not leave Israel. The government of Israel thus decided on the expulsion of those staying in Israel illegally. ${ }^{27}$

From 2005, more than 60,000 illegal immigrants crossed over Israel's southern border with Egypt. Of those 60,000 the overwhelming majority came from Eritrea and Sudan, and there were others from countries such as Ivory Coast, Liberia, Sierra Leone, and Burma. Upon their arrival in Israel, some requested asylum. Other people received "temporary protection." ${ }^{28}$ The floodgates opened in 2007 , and they were closed only in 2012 when the construction of a fence along the Egyptian border was completed.

According to publications of the Population, Immigration and Border Authority (PIBA), as of January 2018, there were approximately 37,228 registered infiltrators in Israel, not including children of infiltrators who were born in Israel. $92 \%$ of them were African citizens, of whom $71 \%$ were Eritreans and 21\% were Sudanese. 3,375 infiltrators left Israel in 2017. On the other hand, 14,778 new asylum requests were submitted to the Ministry of the Interior in $2017 . .^{29}$

23 Goldstein 2004: 397-429.

24 Massey, Taylor 2004.

25 Linde 2011; Sharpe 2018.

26 Schuck 1998: 287.

27 Sabar 2008: 38-44.

28 Temporary protection is an exceptional measure to provide asylum seekers from foreign countries unable to return to their country of origin with immediate and temporary protection. It applies in particular when there is a risk that the standard asylum system is struggling to cope with demand stemming from a mass influx, having a negative impact on the processing of claims. In the EU there is a special Directive concerning Temporary Protection. See: Council Directive 2001/55/EC of 20 July 2001. Available at: http://eur-lex. europa.eu/LexUriServ/LexUriServ.do?uri=OJ:L:2001:212:0012:0023:EN:PDF.

${ }^{29}$ Data on foreigners in Israel, January 2018. Population, Immigration and Border Authority (PIBA)Israel. https://www.gov.il/BlobFolder/generalpage/foreign_workers_stats/he/q1_2018.pdf 
While the Israeli government invested heavily in building the fence on the southern border, very little was done to solve the problem of infiltrators who had already entered the country. These people, mainly from Eritrea and Sudan, were allowed to stay in Israel as they received temporary protection, but most of them were not recognized as refugees. ${ }^{30}$ The Israeli authorities argue that they are not actually refugees and that they have crossed the border, seeking for work and a better life in Israel. The government calls them "infiltrators" or "illegal immigrants" and claims that they are threatening what it calls Israel's "Jewish character." 31

Over the past few years, politicians and activists have focused the illegal immigration spotlight on African asylum seekers in Israel. But quietly, "under the radar," many non-Jewish Ukrainian, Russian and Georgian migrants have entered Israel as tourists and tried to change their status to refugees and remain in Israel. They say their lives are in danger, either due to the conflict in eastern Ukraine or the difficult political situation in Georgia, and they wait in line for days to file an application for refugee status with the Israeli Interior Ministry.

Mr. Deri, the Israeli minister of the interior said in the Knesset (the Israeli Parliament) Interior Affairs Committee on June 2017 that there were 79,000 people from the two Eastern European countries, Ukraine and Georgia, illegally living in Israel. He described a method by which Ukrainian and Georgian citizens pay USD 5,000 each to tourist companies which arrange tourist visas and flights for them to Israel, and then buses to take them to Tel Aviv, where they apply for refugee status. ${ }^{32}$

\section{Some legal aspects concerning the asylum seekers and infiltrators in Israel}

Under Israeli law ${ }^{33}$ an infiltrator is defined as anyone who enters the borders of the state illegally. For our purposes, we will refer here only to infiltrators who arrived across the Egyptian border. An infiltrator can apply for asylum in Israel and their status will then change to asylum seeker. As long as he or she has not submitted such a request, they are officially defined as an infiltrator.

The Israeli authorities are supposed to discuss the asylum application and if it is accepted, the status will change to refugee. This can happen only in accordance with a decision of the state which grants the status of a refugee, considering also the relevant international law and the 1951 Convention Relating to the Status of Refugees and its 1967 Protocol (hereinafter: Geneva Convention). ${ }^{34}$ The status of a refugee is not granted to any person without an official decision of the state. In no case is a person entitled to such status under any other definition.

30 Goldstein 2019: 154-162, note 28.

31 Berman 2016.

32 Harkov 2018.

33 The Prevention on Infiltration Law [1954] No. 5714-1954.

${ }^{34}$ Convention Relating to the Status of Refugees, July 28, 1951, 189 U.N.T.S. 137. There is also an additional Protocol to the Geneva Convention named: International Protocol Relating to the Status of Refugees of 31 January 1967. 
When the immigration authorities in Israel discuss an asylum seeker request, they must consider the Israeli law and the relevant international refugee law that is applicable in Israel.

\section{The 1951 Convention Relating to the Status of Refugees (Geneva Convention)}

A refugee is defined in Article I of the 1951 Convention Relating to the Status of Refugees (Geneva Convention) as a person who is an alien from his country and:

owing to a well-founded fear of being persecuted for reasons of race, religion, nationality, membership of a particular social group or political opinion, is outside the country of his nationality and is unable or, owing to such fear, is unwilling to avail himself of the protection of that country; or who, not having a nationality and being outside the country of his former habitual residence as a result of such events, is unable or, owing to such fear, is unwilling to return to it.

The Geneva Convention does not establish procedures for regulating the status of refugees, and leaves this for the determination of the signatory states. ${ }^{35}$ In other words, according to the Geneva Convention, the State of Israel has the power to determine the legal status of asylum seekers, and who among asylum seekers meets the definition of a refugee. While the Convention determines the basic provisions relating to the status of refugees, the State of Israel operates, as do other member states, and determines the rules and evidence for generating application.

In any case, it is clear by definition that those who immigrate for economic reasons - as severe as they may be - are not entitled to refugee status. This is true as well for those who immigrate due to deprivation of liberty suffered by all citizens of their country, such as forced military service. ${ }^{36}$ Moreover, according to international law, the Geneva Convention does not impose on the signatory countries the absorption of refugees, and the most important principle is the prohibition against expelling them to the state from which they fled (non-refoulement). ${ }^{37}$ It is therefore important to note that according to the Geneva Convention definition of "refugee," the vast majority of infiltrators from Africa to Israel are considered migrant workers and not refugees. ${ }^{38}$

A great deal of criticism has been voiced concerning the Geneva Convention (1951). One of the most acute problems of immigration and illegal aliens stems, according to many scholars, from the incompatibility of the Geneva Convention with the global conditions of the early twenty-first century. The convention, written and signed more than sixty-nine years ago, fails to protect "real" refugees and does not relieve their distress. At the time of the drafting of the Geneva Convention, the world was a different place, where movement was more limited, more difficult, and certainly more expensive. Most

\footnotetext{
35 Goodwin-Gill, McAdam 2007.

36 Goldstein 2019: 366, note 28.

37 Hathaway, Foster 2014.

38 Minnes 2018.
} 
of the refugees who sought refuge did so out of a genuine need - against the backdrop of political, religious and ideological persecution, and so forth. Today in an era of globalization, crossing continents is much simpler than before. Many people from poor countries are trying to change their luck by knocking on the doors of developed countries. Many of them present themselves as refugees and on this basis (and in accordance with the Geneva Convention) plead for political asylum. According to the Geneva Convention, the state must discuss any petition submitted, even if its foundations are very weak. Therefore, even if the chances of, the immigration authorities approving the petition are slim, it provides an immigrant with precious time in which they benefit from the welfare system of the target country and can integrate with the labor market, assimilate into the local population, and even evade the authorities. If their petition is denied in one state, they may file it again in another. This creates a tremendous burden on the system: the enormous number of such petitions makes it difficult for the receiving countries to select the sincere petitions from those who have no basis.

Israel, like any sovereign country in the world, has the right to determine who may enter its borders and is authorized to remove unwanted violators of its borders from its territory.

\section{The asylum process in Israel}

Although Israel is a signatory of the Geneva Convention providing for the protection of refugees, the United Nations High Commissioner for Refugees (UNHCR) handled asylum claims in Israel for decades, until 2009. There is no specific Israeli Immigration law that incorporates the Geneva Convention. In 2009 the Refugee Status Determination Unit (RSD-Unit), which replaced the UNHCR, was founded. Its function was to examine the asylum requests and prepare opinions on the matter. However, asylum requests were sent to the National Status Granting Body (NSGB), a government committee which reviewed asylum claims and granted refugee status. At the request of the Israeli government, the UNHCR was still involved, receiving and sorting asylum requests, interviewing individual cases, and making recommendations to the NSGB, among other tasks. ${ }^{39}$

A new procedure was introduced in 2011. This procedure, called "The handling of asylum seekers in Israel," entered into force on 2 January 2011. The procedure itself has been tried time after time in the Israeli courts and found to be legal. The court ruled that the provisions of this new procedure maintain "a proper balance between human cases, and general policy based on broader considerations." 40

Until 2011, the number of refugees and people seeking asylum in Israel was relatively small. However, according to the UNHCR, the Israeli government's efforts in recent years to reduce the number of illegal workers in the country have increased the number of asylum applications. In 2004, nearly 1,000 refugee status determination interviews took place in Israel; only a few people received refugee status. Most of the asylum

\footnotetext{
39 Berman, note 29.

40 Appeal Case No. 7945/12 Igbokwe Francis Chidi v. The State of Israel (28.11.2013).
} 
seekers were from Ivory Coast, Liberia, Sierra Leone, Eritrea, and Burma. In 2017 alone 14,778 new asylum requests were submitted in this way. ${ }^{41}$

Historically, Israel has viewed asylum as a humanitarian gesture appropriate in only certain isolated instances. The most famous of these was the admittance of several hundred Vietnamese "boat people" in the late 1970s. Approximately one hundred refugees were also admitted from Bosnia in 1993 and nearly 4,000 from Lebanon after the Israeli army completed its withdrawal in May 2000.

In August 2011, a new tribunal was established, serving as a special court of appeal for issues concerning immigrants and asylum seekers and other issues of population administration. In fact, this tribunal is equivalent to the immigration courts that have existed for many years in England, the USA and other countries. The tribunal acts according to the Israeli law and regulations, and customary and conventional international law.

The government of Israel came to a decision on January 2018, that any migrant in the country who agrees to be sent to their home country or to a third country by March 2018 would receive USD 3,500 plus funds for their flight and assistance in arranging travel documents. It must be noted that other programs of "voluntary exit" existed before this last program and thousands of infiltrators had left the country over the years. ${ }^{42}$

\section{Is there a coherent immigration policy in Israel?}

The State of Israel has special needs and interests. Israel is a country that is dedicated to the Jewish people's right to self-determination. The State of Israel has been at war and in ongoing national conflict since its establishment. Therefore, it is a legitimate policy to absorb Jewish Olim in Israel. On the other hand, Israel is considered as a developed country in a developing area, and as a democratic island in an area that is neither democratic nor stable. For these reasons, the State of Israel became a preferred destination for migration of immigrants from various countries in Africa and in recent years also a favorite destination for migration from countries that were once under the Soviet Union, like Ukraine and Georgia.

Migration policy is a tool designed to promote the interests of a state and the people who live in the state. Immigration policies need to address social needs and economic, political, cultural, and security concerns. While trying to formulate an immigration policy Israel must weigh and balance the impact of major five dimensions: security and public order, economic interests, capacity in terms of population size and composition, national and cultural identity, and welfare systems. ${ }^{43}$

Unfortunately, there is no modern law of immigration or refugee law in Israel. This is one of the main reasons that there is no coherent immigration policy in Israel. In 2011, a new immigration law bill was submitted to the Knesset. This bill was not approved. In other words, an attempt was made to regulate the entire issue of immigration through orderly legislation, but it did not work out. Israel signed and ratified the Geneva

\footnotetext{
${ }^{41}$ Goldstein 2019: 139-164, note 28.

42 Ibid.: 396-405.

43 Avineri, Orgad, Rubinstein 2009.
} 
Convention, but the convention was not incorporated into Israeli law. Nevertheless, according to the declarations of the Israeli government in the Supreme Court and according to the procedures of the Ministry of the Interior, the State of Israel operates in accordance with the Geneva Convention.

The current situation can be explained by the fact that the government is interested in having freedom to act without being restricted by legislation. The government of Israel has tried several times to change the laws regarding the prevention of infiltration (1954), but the Supreme Court of Justice in Israel ruled that said laws were unconstitutional. ${ }^{44}$

In the Zegeta case (28 August 2017), ${ }^{45}$ the Supreme Court ruled that if a third country is willing to absorb an infiltrator, the State of Israel has the right to deport him to that country, even against his will. In the special circumstances of the Zegeta case, however, as the third country demanded the infiltrator's upfront consent, it was impossible to deport him. After this Supreme Court ruling, the government passed a decision on 1 March 2018 directing the Population Immigration and Border Authority (PIBA) to plan the gradual, voluntary or non-voluntary removal of infiltrators to a third country. Prime Minister Netanyahu said at the opening of the Cabinet Meeting of 3 January 2018:

Every state must maintain its borders, and protecting the borders from illegal infiltration is also a right and a basic duty of a sovereign state, and we have done two major actions: the first is the construction of the fence, the barrier, against massive infiltration into the land from Africa. On our border with Sinai, prevented the entry of hundreds of thousands of infiltrators who had not arrived in Israel, arrived in other places, but did not reach Israel, and through this tremendous effort, we have reduced the illegal infiltration of Israel to zero, through this border. The second is to remove these, the illegal infiltrators, who infiltrated into Israel illegally. Before we built the barrier, there were about 60,000 people here, we spent about 20,000, and now the task is to spend the remainder, and this year we spent about 4,000, and the great effort is to bring out the majority of those who remain. In Israel, we are now bringing a plan to the government to remove the illegal infiltrators, and this plan will be launched today. ${ }^{46}$

On 2 April 2018 Israel announced, that it had cancelled the contested plan to forcibly deport migrants to Africa, after reaching an agreement with the UNHCR, to allow approximately half of the immigrants to resettle in Western countries and the other half to remain in Israel. ${ }^{47}$

The plan to deport asylum seekers to "a third country" was scrapped after several petitions were filed with the Israeli Supreme court of Justice and when it became clear that the potential third countries did not meet the required conditions, and that those countries could not withstand the pressure.

This agreement with the UNHCR was reached following tough negotiations with the UNHCR. Israel had agreed to resettle one asylum seeker in a Western country for every asylum seeker awarded temporary residency status in Israel. In a statement, the Prime Minister's Office announced that it was estimated that about 16,250 migrants would

${ }^{44}$ Law for the Prevention of Infiltration (Offenses and Jurisdictions) (Legislative Amendments and Temporary Order), 5774-2014.

${ }_{45}$ Appeal Case No. 8105/15 Zegeta v. Ministry of Interior (28.08.2017).

${ }^{46} \mathrm{http} / / / w w w . p m o . g o v . i 1 /$ MediaCenter/SecretaryAnnouncements/Pages/govmes030118.aspx.

${ }^{47}$ Goldstein 2019, note 28: 417-420. 
receive temporary residency in Israel out of the estimated over 38,000 asylum seekers from Sudan and Eritrea who were in Israel in April 2018.

According to the Prime Minister's Office, the deal had been approved by the Israeli Attorney General, Avichai Mendelblit, and it accorded with international law. The office said the new agreement would "allow for a larger number of migrants to leave Israel than the previous plan, and under the auspices of the UN and the international community."48

As a result of a tremendous backlash from politicians and others, over this plan with the UNHCR, Prime Minister Netanyahu announced less than 24 hours after it was unveiled at a news conference, that in the interim, he was suspending the implementation of the agreement, and only after meeting with the representatives would he submit the agreement for re-examination. Finally, Prime Minister Netanyahu announced the cancellation of the agreement with the UNHCR.

\section{Conclusion}

The Basic Plan for Immigration Control is a plan formulated by the Israeli government, which serves as the basis for the measures to control the entry and residence status of foreign nationals, in accordance with the Israeli laws. The most crucial political distinction among migrants is between those of legal versus those of illegal entry. Israel was established in an attempt to create a shelter for Jews in the Diaspora. Those Jewish people (Olim) who arrive in Israel are legitimate citizens and come to Israel within the limits and the purpose of the Law of Return. In this context it is improper to consider Israel as racist, discriminatory, or undemocratic.

Since 2005, more than 60,000 illegal foreign immigrants have crossed over Israel's southern border with Egypt and joined other illegal immigrants that already were in Israel. Of those 60,000 the overwhelming majority came from Eritrea and Sudan. Upon their arrival in Israel, some requested asylum as refugees. The Israeli authorities emphasized that they were not actually refugees, but illegal labor migrants. However, in recent years, a new immigration phenomenon has been occuring in Israel: an increase in foreign nonJewish immigration from Ukraine, Georgia and Russia. This immigration came amid a financial crisis in these countries, plus a continuing territorial dispute between Ukraine and Russia that began in 2014 .

Israel as a sovereign state has the right, as any other country does, to monitor its borders and remove from the country anyone who comes illegally, unless they are legitimate asylum seekers/refugees. In fact, only a small fraction of these people are refugees.

Like other countries, Israel is having second thoughts about the policy towards the expanding phenomenon of foreign immigration. In the aggregate, the share of immigrants who are undocumented affects labor markets, the political valence of immigration, law enforcement, educational opportunities, electoral representation, and other mechanisms of incorporation. The reluctance stems from the fact that immigration is a complex phenomenon - one with positive and negative aspects. Positive aspects are expressed, for example, by economic and demographic benefits. Negative aspects are, for example,

48 Yaron, Landau 2018. 
the objections of the host country, changing the ethnic composition of human/settled tendency in the assimilation of immigrants in the local population. Immigration policy must respond to these aspects. Immigration policy in a changing global reality has become a burning issue in all Western countries. Israel is considered the State of the Jewish people, although Israel has actually become an immigration country that absorbs many people not according to the Law of Return. As of April 2018, 92\% of the infiltrators in Israel $(38,000)$ were nationals of Eritrea or Sudan. Until recently, the policy applied in Israel to subjects from these countries was a "temporary non-removal policy," due to the situation in their countries of origin. There was also a "voluntary exit" program for infiltrators.

Immigration laws which determine immigration policy should be set by the legislative branch. However, the immigration policy in Israel is determined by the executive branch: the Ministry of the Interior and the PIBA. A report released by experts in 2009, alleged that Israel did not have clear migration laws, except the Law of Return and other few unmodern laws. It was said that strategic thinking was lacking, and there was no vision or set goals for the long-term. Moreover, there was no reliable database which serves as a base for policy. Israel did not have full control over immigration from outside the country. ${ }^{49}$

The assessment of an asylum claim can invoke complex questions of refugee law and human rights law. It is important to point out that since 2009 there have been many changes to the immigration policy in Israel. Although there is no specific law of immigration in Israel, the interior office and the PIBA, have made many changes in the immigration procedures and regulations. They set up goals for the long term and revised their database. A special tribunal for appeal was established in 2011. There are fair and satisfactory asylum procedures and strict judicial review. The situation has improved, but because there is no modern law of immigration in Israel, the legal vacuum represents a dangerous flaw that prevents the State from effectively coping with the problem while respecting international, legal and humane standards. Therefore, it is still hard to say that 70 years after the Declaration of Independence there is a coherent immigration policy in Israel.

\section{BIBLIOGRAPHY}

\section{Primary Literature}

Avineri, S., Orgad, L., Rubinstein, A. (2009), Managing Global Migration: A Strategy for Immigration Policy in Israel, Jerusalem (in Hebrew).

Berger, L. (1969), The Impact of Aliya on Israel's Development, Jerusalem.

Berman, J. (2016), The Labyrinth: Migration, Status and Human Rights, Tel Aviv.

Della Pergola, S. (2000), The Global Context in Migration in Israel, in: Elazar, D.J., Weinfeld, M. (eds.), Still Moving: Present Jewish Migration in Comparative Perspective, New Brunswick: 13-60.

Goldstein, R. (2004), Forced Migration Legal Constraints and Future Possibilities, in: Nachmias N., Goldstein, R. (eds.), The Politics of Forced Migration: A Conceptual, Operational and Legal Analysis, Baltimore: 397-429.

Goldstein, R. (2019), Asylum Seekers in Israel in Light of International Law, Tel Aviv (in Hebrew). Goodwin-Gill, G.S., McAdam, J. (2007), The Refugee in International Law, 3rd Ed., Oxford.

\footnotetext{
${ }^{49}$ Avineri, Orgad, Rubinstein 2009, note 43.
} 
Hathaway, J., Foster, M. (2014), The Law of Refugee Status, 2nd ed., Cambridge.

Hollifield, J., Martin, P., Orrenius, P. (2014), Controlling Immigration, Stanford.

Koch-Davidovich, F. (2011), Methods of Immigrant Absorption in Israel, Jerusalem, The Knesset Research and Information Center, 2 February 2011, at: https://fs.knesset.gov.il/globaldocs/MMM/ f2c18d55-f7f7-e411-80c8-00155d010977/2_f2c18d55-f7f7-e411-80c8-00155d010977_11_10184. pdf.

Laskier, M. (2006), Israel and Jewish Immigration from North Africa 1948-1970, Israel (in Hebrew).

Linde, T. (2011), Mixed Migration - A Humanitarian Counter Point, Refugee Survey Quarterly 30, no. 1: 89-99.

Massey, D.S., Taylor, J.E. (2004), International Migration: Prospects and Policies in a Global Market, Oxford.

Minnes, R. (2018), Expelling Illegal Infiltrators from Israel - Legal and Moral, 30 January 2018, at: http://en.mida.org.il/2018/01/30/expelling-illegal-infiltrators-israel-legal-moral (Accessed: 20 April 2020).

Money, J. (1999), Fences and Neighbors. The Political Geography of Immigration Control, London.

Philippov, M. (2008), Why are the Russians Leaving Israel?, The Israeli Democracy Institute, at: https://en.idi.org.il/articles/6754.

Semyonov, M., Lewin-Epstein, N. (2003), Immigration And Ethnicity In Israel: Returning Diaspora And Nation Building, in: Münz, R., Ohliger, R. (eds.), Diasporas and Ethnic Migrants, London: 327-337.

Semyonov, M., Gorodezeisky, A. (2012), Israel: an Immigrant Society, in: Frideres, J., Biles, J. (eds.), International Perspectives: Integration and Inclusion, Montreal and Kingston: 147-163.

Rubinstein, A. (1976), Israel Nationality, Tel Aviv University Studies in Law, no. 2: 159-189.

Sabar, G. (2008), We're Not Here to Stay - African Migrant Workers in Israel and Back in Africa, Tel Aviv (in Hebrew).

Schuck, P.H. (1998), Citizens, Strangers, and In-Betweens - Essays on Immigration and Citizenship, Boulder.

Sharpe, M. (2018), Mixed Up: International Law and the Meaning(s) of "Mixed Migration," Refugee Survey Quarterly 37, no 1: 116-138.

Zapata-Barrero, R. (2010), Theorizing State Behavior in International Migrations: An Evaluative Ethical Framework, Social Research 77, no. 1: 325-352.

Zolberg, A. (1998), Matters of State: Theorizing Immigration Policy, in: International Migration in the Remaking of America, New York.

\section{Press}

Harkov, L. (2017), Deri: Georgians, Ukrainians - The New Migration Problem, Jerusalem Post, 21 June 2017, at: https://www.jpost.com/israel-news/deri-georgians-ukrainians-the-new-migrantproblem-497523 (Accessed: 18 April 2020).

Yaron L. and Landau, N. (2018), Israel Reaches Deal with UN to Deport Asylum Seekers to West, not Africa, Haaretz, 2 April 2018, at: https://www.haaretz.com/israel-news/israel-cancels-forcedasylum-seeker-deportations-after-deal-with-un-1.5973475 (Accessed: 18 April 2020).

\section{Internet sources}

https://www.knesset.gov.il/mmm/data/pdf/me02775.pdf

$\mathrm{http}: / /$ worldpopulationreview.com/countries/israel-population

http://countrymeters.info/en/Israel\#facts

http://eur-lex.europa.eu/LexUriServ/LexUriServ.do?uri=OJ:L:2001:212:0012:0023:EN:PDF

https://www.gov.il/BlobFolder/generalpage/foreign_workers_stats/he/q1_2018.pdf

http://www.pmo.gov.il/MediaCenter/SecretaryAnnouncements/Pages/govmes030118.aspx 


\section{Israeli laws and verdicts}

Law for the Prevention of Infiltration (Offenses and Jurisdictions) (Legislative Amendments and Temporary Order), 5774-2014.

Law of Return, 5710-1950, S.H. 5710, 159; 4 L.S.I. 114.

The Nationality Law, 5712-1952. S.H. 5712, 146; 6 L.S.I. 50.

The Entry into Israel Law (1952). No. 5712-1952.

The Foreign Workers Law (2001). No. 5761-2001.

The Prevention on Infiltration Law (1954). No. 5714-1954.

Supreme Court Appeal Igbokwe Francis Chidi v. The State of Israel (28.11.2013) . No. 7945/12.

Supreme Court Appeal Case Zegeta v. Ministry of Interior (28.08.2017). No. 8105/15.

\section{International conventions}

Convention Relating to the Status of Refugees, July 28, 1951, 189 U.N.T.S. 137. 